Ankara Üniversitesi Türk Inkılâp Tarihi Ensitüsü Atatürk Yolu Dergisi

S 24, Kasim 1999-2003 s. 563-578

\title{
Azerbaycan Cumhuriyeti Devleti'nin Kuruluşunda Türkiye'nin Yardımları İlhak Amacına mı Yönelikti?
}

\author{
Yrd. Doç. Dr. Selma YEL
}

ÖZET

Bu makalede, 28 mayıs 1918'de bağımsızlı̆̆ını ilan etmiş olan Azerbaycan'ın, doğal başkenti olan Bakü'nün Rus, Ermeni ve İngiliz işgalcilerden kurtarlmasında ve Millî Azerbaycan Ordusu'nun teşkilinde Türkiye'nin yardım ve desteği üzerinde durulacaktır. Bu yardımın hangi amaçla yapıldı $\breve{\imath} \imath$, o günden bu güne Azerbaycan ve Rus aydın ve tarihçileri arasında tartışma konusu olup, araştırmamızda bilhassa "Türkiye ilhak amacı ile Azerbaycan'a askeri birlik sevk etmiştir." suçlamasına cevap aranmıştır. Ayrıca, o günün siyasi olaylarına ve kişilerine yer verilmiştir.

\section{Was The Turkish Support During The Establismet Of The State Of Azerbaijan Republic Aimed To Annexation?}

\section{ABSTRACT}

In this article, it was intended to explain Turkey's help and support to Azerbaijan (which was declared its indepen dancy on 28 May 1918) during establisment of national army and rescuing natural capital of Bakü from the occu pation of Russian and Armenian forces. Purpose of Turkey's help and support has long been discussed between Russian and Azerbaijan entellects. In this article, specificially an answer to the claim of "Turkey helped to Azerbaijan with the purpose of, Annexation" has been sought. In addiation, information about political events and characters of thact time was given.

\footnotetext{
* Gazi Üniversitesi Gazi Eğitim Fakültesi.
} 
28 Mayıs 1918'de bağımsızlığını ilan etmiş olan Azerbaycan Cumhuriyeti Devleti, Türk dünyasındaki ilk demokratik-laik ${ }^{1}$ yapısıyla ayrı bir öneme sahiptir. Ömrü kısa sürmüş bile olsa, Azerbaycan'ın bağımsızlı̆̆ını kazanmasında Türkiye'nin tesirli olduğu bilinen bir gerçektir. Fakat bu gerçek, o günden bu güne farklı şekillerde değerlendirilmekte ve Azerbaycan aydınlarından az da olsa bazılarının da iştirak ettiği gibi, Türkiye'nin ilhak amacıyla Azerbaycan'a yardım ettiği iddia edilmektedir. Bu görüşün taraftarı olanlar, gerekçe olarak daha çok da Enver Paşanın "Turancı" oluşunu bahane etmektedirler. Kısmen bu görüş doğru olmakla birlikte, Türkiye'nin yardımının, Azerbaycan ve Kafkasya Türk-İslam halkından gelen davet üzerine gerçekleştiği hususunu ise görmezden gelmektedirler.

Bolşevik Rus ihtilalini müteakip, çarın hakimiyeti altındaki bütün esir milletler bağımsızlıklarını kazanmak için mücadeleye başlarken, Kafkasya'daki Müslüman halk da teşkilatlanma çabası içine girmiştir. Gürcüler ve Ermeniler amaçlarına ulaşma hususunda daha avantajlı konumundadırlar. Rus ordusu ve devlet kademelerinde görev yapmış oldukları için ordu ve devlet teşkilatı tanziminde daha tecrübeli hareket etmektedirler. Türk-İslam toplulukları ise özellikle bu tarz görevlerden uzak tutulmuş oldukları için acil yardıma ihtiyaç duymaktadırlar. Her zaman olduğu gibi yine tek yardım makamı Türkiye'dir.

Aynı dönem içinde Kafkasya Müslüman halkı arasında yoğun bir işbirliği ve fikir teatisi sürecinin başladığ ${ }_{1}$ görülmektedir. 15-20 Nisan 1917'de Bakü'de Kafkasya Müslümanları'nın geleceğini belirlemek amacı ile bir kurultay yapılmıştır². Bu kurultayda Müsavat Halk Partisi ile Türk Ademî Merkeziyet Partisi'nin ${ }^{3}$,

\footnotetext{
' Ahat Andican, "Güçlü Bir Azerbaycan Türk Cumhuriyetleri ve Kafkasya İçin Şarttır." Azerbaycan Kültür Dergisi, Sayı: 315, 1987, Yıl.47, S.19.

${ }^{2}$ Mirza Bala Mehmetzade, Milli Azerbaycan Hareketi, Ankara, 1991, S.83.

${ }^{3}$ Dursun Çelik, "XIX ve XX. Yüzyıllarda Azerbaycan” Bilgi ve Kültür Dergisi, Sayı:3, 1996, S.68, Müsavat Halk Partisi 1911'de Sosyalist demokrat ve liberal sağ kanat mensuplarının bir araya gelmesiyle kurulmuştu. Aslında Azerbaycan'da ilk kurulan parti "Himmet" idi. Fakat 1907 'de Ruslar tarafından kapatıldığı için tesirli olamamıştı. Müsavat ise diyebiliriz ki, kurulduğu günden 2000'li yıllara kadar Azerbaycan halkı için önemini muhafaza edebilecekti. Parti programına göre; Müslümanlar'la Ruslar'a eşit haklar verilmesi ve tüm Türk-İslam dünyasının istiklâlinin kazanılmasında yardımcı olunması amaç edinilmişti. Parti başkanı, daha önce Himmet Partisi'nin de kurucularından olan büyük yurt sever ve Türkçü Mehmet Emin Resulzade idi. Partinin programı şöyleydi:

1. Milliyet ve mezhep farkı gözetmeden bütün Müslümanları birleştirmek,

2. İstiklâllerini kaybetmiş Müslüman memleketlerin yeniden müstakil olmalarına çalışmak,

3. İstiklâllerini müdafaa veya ihya için çarpışan bütün Müslüman memleketlerine maddî ve manevî yardımda bulunmak,

4. Müslüman milletlerin ve memleketlerin savunma ve taarruz kuvvetlerini artırmak için yardım etmek,
} 
ağırlıklı hakimiyeti altında gelişen tartışmalardan sonra şu kararlar alınmışt1 ${ }^{4}$.

1. Kafkasya Müslüman Kurultayı millî, siyasî maksatlar hakkındaki konuları tartışarak, Müslüman milletlerin menfaatlerini en fazla temin edecek olan idarecilerin, mahallî federasyon esası üzerinde kurulu cumhuriyet idaresi fikrini kabul edecektir.

2. İslam dininde olan bütün milletlerin ruhanî ve medenî irtibatını dikkate alarak, Kafkasya Müslüman Kurultayı bütün Rusya Müslümanları'ndan aldığı güçle genel bir idare teşkilini lüzumlu görmektedir.

Kurultay görüşmelerinden sonra, islamcılar, sosyalistler ve milliyetçiler arasındaki görüş ayrılıkları iyice açığa çıktığı için milliyetçi ve islamcı görüşleri savunan "Müsavat Halk Partisi" ile "Türk Adem-i Merkeziyet Partisi" birleşmişti ${ }^{5}$.

Kurultayda yoğun fikir ayrılıkları ortaya çıkmış bile olsa, her kesimin birleştiği husus, bağımsızlığın mutlaka kazanılması gerektiğiydi. Lenin bu gelişmelerden tedirgin olduğu için 18 Aralık 1917'de Stepan Şaumyan'1 Kafkasya Fevkalade Komiserliğine tayin edecekti. Aynı zamanda Türkiye'yi de yakından ilgilendiren bir beyanname yayınlayarak, Türkiye Ermenistanı olarak kabul ettirmeye çalıştıkları bölgedeki Ermeni halkının istiklâlini temin hususunda yardımcı olunacağını ilan etmişti ${ }^{6}$. Lenin, bu beyanname ile Doğu Anadolu ve Kafkasya'da nasıl bir politika takip edileceğini alenîleştirmiş olduğu için Türkiye'nin karşı tedbirler alması gerekmekteydi. Aynı zamanda Kafkasya'da giderek artmakta olan Ermeni tedhiş ve mezalimine karşın da kayıtsız kalınması mümkün görünmüyordu?

5. Bu fikirlerin yayılmasına mani olan bütün engellerin ortadan kaldırılmasına yardım etmek,

6. Müslümanların birleşmesine ve ilerlemesine çalışan bütün partilerle bağlantı kurmak,

7. İnsanlığın refahı ve ilerlemesi için çalışan bütün partilerle bağlantı kurmak,

8. Müslümanların yaşaması için gerekli olan ticarî, sanayî ve ekonomik hayatı kuvvetlendirmek için her türlü vasıtayı kullanmak.

Türk Adem-i Merkeziyet Partisi ise Şubat 1917 ihtilalini müteakip kurulmuştu. Bu parti de, Türkiye'deki Adem-î Merkeziyet Cemiyeti'ne isim, program ve tüzügü ile benzerlik gösteriyordu. Türkçülük esasına dayanan programları, Gence halkının çoğunluğu tarafından destekleniyordu. Parti lideri, İsmail Gaspıralı'nın damadı olan Nasib Yusufbeyli idi. Aynı zamanda Azerbaycan'ın ilk millî eğitim ve maliye bakanı olacaktı.

${ }^{4}$ Mehmetzade., Millî Azerbaycan..., s.48, vd; Cemil Hasanlı, Azerbaycan Tarihi, ANK., 1998, s.31-32

${ }^{5}$ Mehmetzade., Milli Azerbaycan..., s.50, vd; Hasanlı., Azerbaycan Tarihi..., s.34.

${ }^{6}$ Mehman Süleymanov, Qafgaz İslam Ordusu ve Azerbaycan, Bakı, 1999, s.46, vd; Hasanl., Azerbaycan Tarihi..., s.40

${ }^{7}$ Dağılarak evlerine dönmekte olan Rus askerleri bilhassa müslüman halkı soyup, taciz ederken, yaklaşık 200 köyü yok etmişlerdi. Benzer hadiselerde Ermeniler'in rolü olduğu 
Kafkasya Müslümanları'nın bağımsızlık taleplerinin giderek artması üzerine, Stephan Şaumyan 31 Mart 1918'de Bakü'de 14 bin Müslüman'ın katliamı ile neticelenen büyük bir tedhiş eylemi gerçekleştirecekti ${ }^{8}$. Azerbaycan tarihine "Mart Kırgını" olarak geçen bu hadise, Kafkasya Müslümanları'nın kendi başlarına bağımsızlıklarını kazanmalarının mümkün olmadığını göstermişti. Fakat, Azerbaycan nasıl bir politika takip edeceği hususunda tereddüt yaşamaktaydı. Maveray-i Kafkas Konfederasyonu', ile siyasî beraberliğini devam ettirmek ya da Türkiye ile ittifak yapmak seçeneklerinden birisini tercih etme durumuyla karşı karşıya kalınmıştı. Aslında Türkiye, 18 Aralık 1917'de imzalamış olduğu Erzincan Mütarekesi ile Maveray-i Kafkas Konfederasyonu'nu da tanımış oluyordu ${ }^{10}$. Fakat diğer taraftan da Gürcistan ve Ermenistan ile sınır ihtilâfı devam ediyordu.

Türkiye'nin içinde bulunduğu bu durum, konfederasyon mensubu olan Azerbaycan'ı taraf tutmaya zorluyor ve problem çıkmasına sebep oluyordu. Gürcistan ve Ermenistan, Türkiye ile silahlı mücadele kararı verirken, Azerbaycan aksine, Türkiye ile dostane politika takibinden yanaydı.

3 Mart 1918'de imzalanmış olan Brest-Litovsk Antlaşması, Elviye-i Selâse'yi Türkiye'ye bırakırken, Gürcistan'ın yoğun tepkisine sebep olmuş, fakat Türk askerî harekâtı üzerine 28 Mart 1918'de antlaşmayı tanımak mecburiyetinde kalmıştı ${ }^{11}$. Akabinde de taraflar arasındaki ihtilâflı konuları çözümlemek için önce Trabzon Konferansı yapılmış, arkasından da 11 Mayıs 1918'de Batum Konferansı'na başlanmıştı ${ }^{12}$.

Türkiye temsilcileri bir taraftan konferansa iştirak ederken, diğer taraftan da, Kafkasya ve Türk dünyasının farklı bölgelerinden Batum'a gelmiş olan

bilinmekte idi. Bu hadiselerin yoğunlaşmasında Ruslar'ın, Gürcü ve Ermeniler'e silah dağıtması tesirli oluyordu. Geniş bilgi için bkz: Hasanlı., Azerbaycan tarihi..., s.40

${ }^{8}$ Hasanlı., Azerbaycan Tarihi..., s.34, vd; Mehmetzade., Milli Azerbaycan..., s.85, Bakü karadan, denizden ve havadan bombardıman edilmişti. Camiler, okullar, matbaa ve tiyatrolar, kütüphaneler ateşe verilmişti. İsmail Berkok, "Büyük Harpte Şimalî Kafkasya'daki Faaliyetlerimiz ve 15. Fırka'nın Harekâtı ve Muharebeleri”, 94. Sayı, Askerî Mecmua'nın 44 Sayılı Tarih Kısm1, IST., 1934, S.5

${ }^{9}$ Akdes Nimet Kurat, Türkiye ve Rusya XVIII.Yüzyıl Sonundan Kurtuluş Savaşı'na Kadar Türk-Rus İlişkileri (1889- 1919), ANK., 1970., S.458, vd; Selma Yel, Yakup Şevki Paşa ve Askerî Faaliyetleri, ANK., 2002, S.33-34, Rus Bolşevik ihtilalini müteakip, Pedrograd'daki geçici hükümet Gürcü ve Ermeni ileri gelenlerinin gayretleri neticesinde Maveray-i Kafkas Konfederasyonu'nun teşkiline izin vermişti. Azerbaycan da bu birliğe dahil olmuştu. Bolşevikler, Petrograd geçici hükümetine son vererek iktidarı ele geçirince, Maveray-i Kafkas Konfederasyonu da 15 Kasım 1917'de Rusya'ya karşı bağımsızlığını ilan etmişti. Konfederasyonun merkezi Tiflis olmuştu.

${ }^{10}$ Kurat., Türkiye ve Rusya..., s.464, vd; Yel., Yakup Şevki Paşa ve..., s.34

${ }^{11}$ Atese Arş, Klas., 6863, Dos.34, F.1-5, 1-7, vd; Kurat., Türkiye ve Rusya..., s.468 vd; Yel., Yakup Şevki Paşa ve ..., s.45

${ }^{12}$ Yel., Yakup Şevki Paşa ve ..., s.52, Nasır Yüceer, Birinci Dünya Savașı'nda Osmanlı Ordusu'nun Azerbaycan ve Dağıstan Harekâtı, Ank., 1996, S.29. 
temsilciler ile görüşmekteydiler. Bolşevik ihtilalinden sonra Kırım, Kazan, Türkmenistan, Hive, Buhara, Kazakistan, Kuzey Kafkasya ve Azerbaycan'1 temsil eden gruplar, Batum'dan Trabzon'a ve İstanbul'a kadar uzanan geniş bir ilişkiler ağı geliştirmişlerdi ${ }^{13}$.

Türkiye ile yakın siyasî ilişki kurabilmesi için Azerbaycan'ın konfederasyondan ayrılması gerekiyordu. Beklenen fırsat kendiliğinden zuhur edecek ve Gürcistan, Almanya'nın himayesini temin edince konfederasyondan ayrilacaktı. Bunu Ermenistan takip ederken Azerbaycan'ın önünde hiçbir engel kalmadığı için 28 Mayıs 1918'de bir deklârasyonla bağımsızlığını ilan edecekti. Meclis açılıncaya kadar geçici şûra ilan edilerek, başkanlığa Mehmet Emin Resulzade seçilmişti. 9 kişilik icra heyetinin başkanlığına da F.H. Hoyski getirilmiş, H.Agayev ve M. Seyidov başkan yardımcısı olmuşlard $1^{14}$.

Azerbaycan'ın bağımsızlı̆̆ını ilan etmesinde, Türkiye'nin telkin ve tavsiyeleri tesirli olmuştu. Fakat, bağımsızlığını devam ettirebilmesi ve doğal başkenti Bakü'nün Bolşevikler ve Ermeniler'den kurtarılabilmesi için de yardıma ihtiyacı vardı. ${ }^{15}$ Türkiye'den resmî olarak yardım istenmesi gerekiyordu. Bu da şûra üyeleri arasında tartışmalara sebep oluyordu. Nasib

${ }^{13}$ Yel., Yakup Şevki Paşa ve ..., 33.34, Bu hususta geniş bilgi için bkz; Hüsamettin Tugaç, Bir Neslin Dramı, İST., 1975, S.185, vd; Ahmet Refik Altınay, Kafkas Yollarında, ANK.., 1986, Bu konuyla ilgili daha geniş bilgi için bkz; Naki Keykurun, Azerbaycan İstiklâl Mücadelesinden Hatıralar (1905 - 1920), ANK.,1998. Yazar, Azerbaycan'da bağımsızlık mücadelesi veren "Difai" teşkilatının başkanı olup, aynı zamanda Türk Adem-î Merkeziyet Partisi mensubudur. Sibirya'dan esaretten kaçmış olan Türk subayı Hüsamettin Tugaç'ın yardımları ile silahlı milis gruplar oluşturup, Gence ve çevresindeki Rus ve Ermeniler'in yıkıcı faaliyetlerini engellemeye çalışmıştır. Daha sonra yine H. Tugaç'la birlikte Mehmet Emin Resulzade'nin emriyle Türkiye'ye gelerek, Millı̂ Şûra'nın yardım talebini iletmişlerdir. Kafkas Türk askerî harekâtının başlamasında, getirdikleri stratejik bilgilerin tesirli olduğu bilinen bir gerçektir.

${ }^{14}$ Mehmetzade., Milli Azerbaycan Hareketi..., s.83. Deklârasyonda ilan edilen hususlar şunlardı: "1- Bu günden itibaren Azerbaycan halkı, hakimiyet hakkına malik olduğu gibi Cenubî ve Şarkî Maverayi Kafkasya'dan ibaret Azerbaycan dahi kamîle hukuk müstakil bir devlettir. 2- Müstakil Azerbaycan devletinin şekli idaresi halk cumhuriyeti olarak takarrur eder. 3- Azerbaycan Halk Cumhuriyeti bütün milletlerle ve bilhassa hem civar olduğu millet ve devletlerle münasebeti hasene tesisine azmeder. 4- Azerbaycan Halk Cumhuriyeti millet, mezhep, sınıf ve cins farkı gözetmeden kalemrevinde yaşayan bütün vatandaşlarına hukuki siyasiye ve vataniye temin eyler. 5- Azerbaycan Halk Cumhuriyeti arazisi dahilinde yaşayan bil-cümle milletlere serbestane inkişafları için meydan bırakır. 6- Meclis-i Müessesan toplanıncaya kadar Azerbaycan idaresinin başında ârayi umumiye ile intihab olmuș Şûra-i Millî ve Şûra-i Milliye karşı mesul hükümet-i muvakkate durur", Yüceer., Birinci Dünya Savaşı'nda ..., S.31.

${ }^{15}$ Yüceer., Birinci Dünya Savaşı'ında ..., S.36, Sadece Azerbaycanlılar değil bütün Kafkasya Müslümanları'nın kendilerini koruyacak bilgi ve imkanları mevcut değildi. Türkler bilinçli olarak askere alınmamışlar, sevk ve idare hususunda tecrübesiz bırakılmışlardı. Gürcüler ve Ermeniler ise aksine, çar ordusunda üst makamlara kadar çıkabilmişlerdi. 
Yusufbeyli'nin şu sözlerinde bu durumu açıkça müşahede etmekteyiz. “...hatır için hasta düşebilmeliyiz. Bizim heyetin Batum'a giderek Şarkî Maverayi Kafkasya Türkler'i namından Osmanlı Devleti'nden yardım istemesi zamanı gelmiştir. Fakat bununla beraber, Azerbaycan istiklâli idaresini de hiçbir vakit unutmamalıyız..."16. Bu ifadede de görüldüğü gibi şûra üyeleri, Türkiye'nin davet edilmesi halinde, Azerbaycan'ın bağımsızlığının yok olacağından endişe duymaktaydılar. Bazıları ise, açıkça Rusya ile siyasî ilişki kurulması gerektiğini müdafaa ediyorlardı. Müsavat Partisi gibi Azerbaycan milliyetçileri ile Sosyalist Bloku ve Himmet Partisi gibi solcu partiler, kayıtsız şartsız Türkiye hayranlığını ve bağlılığını tasvip etmiyorlardı. İlhakçı görüşü müdafaa edenler daha çok din adamları, tüccarlar olmakla birlikte, turancı görüşlere sahip olan Ahmet Ağaoğlu ve Doktor Karabey gibi bazı aydınlar da mevcuttu. ${ }^{17}$

Türkiye'nin bu süreçte, Azerbaycan'a yardım hususunda istekli olduğu görülmekle birlikte, mahiyeti açık değildi. 4 Haziran 1918'de imzalanmış olan Azerbaycan- Türkiye Dostluk Anlaşması gereğince, yardım yapılabilmesi için böyle bir hak doğuyordu. Anlaşmaya göre;

1. Azerbaycan ile Türkiye arasında daimî bir dostluk ve barış olacaktı,

2. Azerbaycan, Türkiye, Gürcistan ve Ermenistan arasındaki sınırlar belirlenmişti. Bu durumda Türkiye ve Azerbaycan arasında geniş bir sınır komşuluğu tesis edilmiş oluyordu,

3. Azerbaycan, Gürcistan ve Ermenistan arasındaki ihtilaflı sınır konusu çözümlenecek ve Türkiye'ye bildirilecekti,

4. En önemli madde olup, Azerbaycan huzur ve istikrarını, güvenliğini temin edebilmek için ihtiyaç duyması halinde Türkiye'den askeri yardım talebinde bulunabilecekti,

5. Sınırları içindeki silahlı çetelerin bertaraf edilmesi sorumluluğu Azerbaycan'a aitti ${ }^{18}$.

Azerbaycan, Türkiye arasındaki dostluk anlaşmasında sıkı bir işbirliği söz konusu olmakla birlikte, Azerbaycan'ın bağımsızlığından bahsedilmemiş olması, daha sonra muhalif gruplar ve özellikle de Rusya tarafından eleştiri konusu yapılacaktı. Türkiye'nin hangi ölçüler içinde Azerbaycan'a yardım yapacağı hususunda da sınırlandırmalar getirilmediği için ikili ilişkilerde

\footnotetext{
${ }^{16}$ Mehmetzade., Milli Azerbaycan Hareketi..., s.87

${ }^{17}$ Tadeusz Swietochowski, Müslüman Cemaatten Ulusal Kimliğe Rus Azerbaycanı 19051920, Çev: Nuray Mert, IST., 1988, S.239.

${ }^{18}$ Hasanlı., Azerbaycan Tarihi..., s.100-101, Anlaşmayı Türkiye adına Doğu Cephesi III. Ordu kumandanı Vehip Paşa, Azerbaycan adına Dışişleri Bakanı M.H. Hacınski ve Milli Şûra'nın Başkanı Mehmet Emin Resulzade imzalamıştı. Anlaşmanın diğer maddelerinde de demiryolu yüklerinin taşınmasında tarafların sorumluluklarından, serbest ticaretten, Azerbaycan'ın uluslar arası posta- telgraf ittifakına girmesinden bahsedilmekteydi. BrestLitovs Antlaşması taraflar arasında da geçerli olacaktı.
} 
zaman zaman problemler yaşanmaya başlayacaktı ${ }^{19}$. Türkiye'ye yönelik suçlamalar daha çok Türk askerî yardımının, Kafkasya ve Azerbaycan topraklarının ilhakı amacına yönelik olduğu konusunda yoğunlaşmaktaydı.

Amerika'da yaşamakta olan tarihçi Prof. Dr. Tadeusz Swietochowski'nin “Müslüman Cemaatten Ulusal Kimliğe Rusya Azerbaycanı 1905-1920" adlı eserinde de bilhassa bu iddianın desteklendiği görülmektedir. Üstelik eser, Azerbaycan aydınlarının bir kısmı tarafından objektif ve bilimsel bir çalışma olarak kabul edilerek, referans verilmektedir ${ }^{20}$.

Enver Paşanın ve Türkiye'nin bu husustaki plânlarının mahiyetinin tam manasıyla açık olmadığı hususu büyük ölçüde doğrudur. Bu sebeple kaynaklar farklı yorumlar getirmektedir. Bu kaynaklar içinde önemli bir yeri olan Şevket Süreyya Aydemir'e göre; Enver Paşanın savaşın başından itibaren Kafkasya ile ilgili büyük beklentisi ve plânları mevcuttu. Bu plânın ana hatları şöyleydi:

1. Savaşın sona ermesini müteakip Türkiye, Almanlar'la birlikte İran Azerbaycanı'nda nüfuz sahibi olacaktı ${ }^{21}$.

2. Azerbaycan'da bağımsız bir hükümet kurulacak, fakat başına gelecek olan başkan geçici olacaktı. Daha sonra Türkiye, Enver Paşa ile Şark Ordular Grubu kumandanı Halil Paşa arasında kimliği bir sır olarak saklanmakta olan bir hükümdar tayin edecekti, ya da Enver Paşanın yakınlarından birisi, muhtemelen de kardeşi Nuri Paşa bu göreve atanacaktı ${ }^{22}$.

${ }^{19}$ Vilayet Guluyev “Osmanlı Vesayeti” ELM (ILLIM) Gazetesi, 23 Eylül 1989

${ }^{20}$ Vilayet Guluyev "Osmanlı Vesayeti" a.g.m., Bizzat makalenin yazarı da T. Swietochoeski'nin objektif olduğunu idida etmekle birlikte, Azerbaycan aydınlarının bir bölümü tarafından da "Burjuva Bilimcisi" olarak suçlandığını ifade etmek mecburiyetinde kalmıştır. Cemil Hasanlı ise "Azerbaycan Tarihi 1918-1920" adlı mufassal eserinde, Tadeusz Swietochowski'den sık sık alıntı yapmakla birlikte, zaman zaman görüşlerini eleştirmiş ve çürütme yoluna gitmiştir.

${ }^{21}$ Bu durumun İran tarafından da müşahâde edildiği görülmektedir. Türkiye'nin yardımıyla Azerbaycan'ın Tebriz'i ilhak edeceği düşünülmektedir. Türk askerinin Haziran 1918 'de Tebrîz'i bu amaçla işgal ettiğini iddia etmektedirler. Azerbaycan, İran'ın şüphelerini bertaraf etmek için resmî yazışmalarda "Kafkas Azerbaycanı" ifadesini özellikle belirtmeye başlamıştır. İran Azerbaycanı şimdilik kaydıyla konu edilmemesine rağmen, Enver Paşanın Kafkas Azerbaycanı ile İran'ın hakimiyeti altındaki Azerbaycan topraklarını birleştirmeyi plânladığı bilinmektedir. Bu hususta geniş bilgi için bkz: Yel., Yakup Şevki Paşa...a.g.e. vd. ELM (ILLIM) Gazetesi, 23 Eylül 1989.

${ }^{22}$ Şevket Süreyya Aydemir, Makedonya'dan Ortaasya'ya Enver Paşa 1914-1922, C.III, İST., 1978, S.367, Enver Paşanın plânları oldukça kapsamlı olup, Kuzey Kafkasya ve Dağıstan'ı içine almaktadır. Buralarda bir devlet geleneği mevcut olmadığı için Rus istilasından kurtarıldıktan sonra nasıl bir hükümdar tayin edileceğine henüz karar verilmemiştir. Türkistan ve Trablusgarp için de bir hükümdar adayı gerektiğini düşünmektedir. Hali hazırda Trablusgarp'te İtalyanlar'a karşı muharebelere devam etmekte olan Şehzade Osman Fuat Efendi bu iş için düşünülenler arasındadır. Aynı kaynak, Enver 
Enver Paşanın plân ve düşüncelerine yakından şahit olanlardan birisi de Naki Keykuron'dur ${ }^{23}$. Enver Paşa ile görüştügüünde, "Kafkas İslam Ordusu" nun çoktan teşkil edilmiş olduğunu belirterek, "...şimdi sizi müstakbel Kafkas İslam Ordusu Kumandanı Prens Faruk ile tanıştıracağım..." sözleriyle içeriye giren genç bir subaya takdim edildiğini ifade etmektedir. Bu durumun Şevket Süreyya Aydemir'in verdiği bilgilerle paralel olduğu görülmektedir. Anlaşıldığı üzere, Ömer Faruk Efendi, Trablusgarp'tan Azerbaycan'a gönderilmek amacıyla İstanbul'a çağrılmıştır. Bu sebeple, Enver Paşanın Azerbaycan'ın başına Osmanlı hanedanından birisini getirmek suretiyle idare etmek istediği iddiası açıklık kazanmaktadır. Enver Paşanın daha sonra bu karardan vazgeçtiği görülmektedir. Bu değişiklikte Naki Keykuron'ın belirttiği gibi, “....sizin Kafkasya'ya gidecek askerlere kumandan tayin ettiğiniz prensi her akşam Pera Palas Oteli'nin salonunda içki içip, dans ederken görüyorum. Kafkasya'da böyle hallerden hoşlanmazlar." ${ }^{24}$ şeklindeki uyarısı tesirli olmuş olabileceği gibi, en yakınlarından birisi olan Nuri Paşayı daha güvenilir bulduğu için bu göreve atanmasını gerçekleştirmiş olma ihtimali de mevcuttur ${ }^{25}$.

Nuri Paşa da, Ömer Faruk Efendi gibi Trablusgarp'te Misrata Cephesi kumandanı olarak görev yaparken İstanbul'a çağrılmıştı. Yaşı küçük, rütbesi de düşüktü. Hızla terfi ettirilerek yarbay yapılmasına rağmen, ordu kumandanlı̆̆ı yapması mümkün değildi. Bu sebeple özel bir kanunî düzenlemeyle Sultan V. M. Reşat, “...bütün Kafkas İslam Orduları ve bölgeleri için bir vekalet veya bir nevi emirlik fermanı verdi. ${ }^{26 "}$ Böylece Nuri Paşa fahri ferik ünvanıyla Azerbaycan'dan sorumlu İslam Ordusu kumandanlığına getirilirken, Halil Paşa da, Şark Ordular Grubu kumandanı olarak bölgenin en üst düzey askerî yetkilisi olmuştu.

Enver Paşanın, Kafkasya bölgesindeki üst düzey atamalarda yakınlarından kişileri seçmesi, bölgeyle ilgili açıklamakta tereddütlü olduğu plânların varlığını akla getirmektedir. Bu takdirde de, "Azerbaycan'ı ilhak etmek istiyordu" tezini müdafaa edenlere hak vermek gerekmektedir, ya da Ali Fuat Cebesoy'un nakletmiş olduğu görüşe katılmak mümkündür. Buna göre; Enver Paşa, Kafkasya’ya özel bir önem atfetmektedir. Bir mağlubiyet sonrasında, Kafkaslar'daki Türk askerî birlikleri ile merkezi Bakü olmak üzere geçici bir hükümet teşkili ile teklif edilen barış antlaşmasının ağırlığı derecesine göre, anavatanı kurtarmaya çalışacaktır²7. Savaşın Türkiye'nin

Paşanın hayallerinin sınırsız olduğunu ve savaşın galibiyetle bitmesi halinde Osmanlı tahtında da değiş̧iklikler yapmayı tasarladığını ifade etmektedir.

${ }^{23}$ Keykuron., Azerbaycan İstiklâl..., s.100

${ }^{24}$ Keykuron., Azerbaycan İstiklâl..., s.101

${ }^{25}$ Aydemir., Makedonya'dan Ortasaya'ya..., s. 359

${ }^{26}$ Aydemir., a.g.e., s.360

${ }^{27}$ Yel., Yakup Şevki Paşa ve ..., s. 57, vd; Ali Fuat Cebesoy, Milli Mücadele Hatıralarım, isT., 1953, s.42, Kurat., Bakü değil, Kars şehri olma ihtimali üzerinde durmaktadır. Çünkü Kars, Anadolu'ya daha hakim bir noktadır görüşündedir. Bkz; Kurat., 
mağlubiyeti ile bittiği kesinleştiğinde, Nuri ve Halil Paşaya Türkiye'ye dönmemelerini emrederek, en kısa zamanda kendisinin de onlara katılacağını belirtmesi ${ }^{28}$ sebebiyle, bu ihtimal daha güçlü görünmektedir. Fakat, bu durumdan Enver Paşanın Azerbaycan'ı bütünüyle ilhak etmeyi düşündüğü sonucunu çıkarmak mümkün değildir. Halil Paşanın hatıralarında da, bu istikamette bilgi mevcut değildir. Sadece Azerbaycan'da sıkı bir idare temin etmeyi düşünmüş olduğu görülmektedir. Aksi takdirde, Irak politikasındaki açıklık ve kesinliğin Azerbaycan için de söz konusu olması gerekirdi. Enver Paşa, savaşın başından itibaren Bağdat'ı ele geçirerek, Irak'ı yeniden Türkiye topraklarına ilhak etmeyi plânlamıştı. Bu durum bir çok kaynakça teyit edildiği gibi, atese arşiv belgelerinde de müşahede etmek mümkündür ${ }^{29}$.

Enver Paşanın Kafkasya'ya verdiği önemin gerisinde aslında yine Türkiye'nin güvenliğini temin etme çabasının olduğu bir gerçektir. BrestLitovsk Konferansı başlangıcında, Rusya'nın ileride yeniden güçlenmesi ihtimaline karşı, Azerbaycan ve Dağıstan'ı bir islam devleti şeklinde teşkil ettirerek Türkiye sınırında tampon ve dost bir devlet oluşturma plânını gerçekleştirme teşebbüsünde bulunmuştur. Fakat bu plân ne Almanya ne de Rusya tarafından tasvip edilmemiştir. ${ }^{30}$ Enver Paşa, islam devleti kurma plânını yine de gerçekleştirmeye çaba göstererek, Azerbaycan ve Dağıstan'ın bağımsızlığını temin amacıyla Kafkas İslam Ordusu'nu teșkil etmiștir. Özellikle dikkat edilen husulardan bir diğeri ise bağımsızlıklarını kazanmalarından sonraki süreçte, her iki devletin de Türkiye'ye siyasî yönden bağlılıklarını temin etmektir. Fakat, temelde Enver Paşanın daimî olarak, Azerbaycan ve Dağıstan gibi kadim Türk illerini işgalcilerden kurtararak, hakiki sahiplerine verme düşüncesinden de hiçbir zaman vazgeçmediği bilinen bir gerçektir. ${ }^{31}$ Bu uğurda, Almanya ile Türkiye'nin askerî ve siyasî ilişkilerinin bozulmasını dahi göze alabilecektir. Zira, Türkiye-Azerbaycan yakınlaşması neticesinde Almanya Rusya ile Brest-

Türkiye ve Rusya..., s. 573, Fakat, Ali Fuat Cebesoy'un iki şehri karıștırma ihtimali zayıf görünmektedir. Üstelik Enver Paşa Kars'a değil, Bakü'ye gitme düşüncesinde olduğunu, Osmanlı Devleti'nin mağlubiyeti sonrasında Nuri ve Halil Paşalara bildirmiştir.

${ }^{28}$ Yel., Yakup Şevki Paşa ve ..., s.70, vd; Şevket Süreyya Aydemir. "Son Osmanlı Paşası Halil Kut'un Hatırası" Akşam Gazetesi (10Aralık 1967) s.4 Halil Paşa, bu emri yerine getiremeden İstanbul'a dönmüş, Nuri Paşa ise Enver Paşa ile buluşamadan Bakü'ye giren İngilizler tarafından tutuklanmıştı.

${ }^{29}$ Yel., Yakup Şevki Paşa ve ..., s.58, vd; ATESE ARŞ., 1/1, Klas., 137, Doo., 632, Fih., $3,3-1$

${ }^{30}$ Swietochowski., Müslüman Cemaatten..., S.181, Musa Kasımov, "20. Asır Azerbaycan Tarihinde; 1920-1922 Yıllarındaki; Azerbaycan-Türkiye Diplomatik -Siyâsî Alâkalar”, Türk Dünyası Araştırmalanı, Sayı:124, Şubat 2000/01, S.113, Yüceer., Birinci Dünya Savaşı'nda..., S.16.

${ }^{31}$ Yüceer., Birinci Dünya Savaşı'nda..., S.30. 
Litovsk Anlaşması'na ek bir protokol düzenlemiştir. ${ }^{32} \mathrm{Bu}$ protokol tamamiyle Türkiye'nin askerî politikalarına ters esaslar içermektedir.

1928 'den vefatına kadar Mehmet Emin Resulzade'nin yanında bulunan ve Azerbaycan'ın Sovyet işgali sonrasında kurulmuş olan Genç Azer Teşkilatı (Musavvat'ın yer altı gençlik gizli teşkilatı) üyesi olan Dr. Mehmet Kengerli de bu görüşleri tasdik etmiş olup, Enver Paşanın padişah olmak ya da Azerbaycan'ı ilhak etmek düşüncesinde olmadı̆̆ını belirtmektedir. Bu tür iddiaların ideolojik olarak, bilhassa Sovyet aydınları tarafından öne sürülen faraziyeler olduğunu ifade etmektedir. ${ }^{33}$

Nuri Paşanın yetkilerini incelediğimizde de aynı kanaatin doğruluğu görülecektir. Yetki belgesine göre;

1. Kafkas İslam Ordusu'nun teşkilinden amaç, Kafkasya'da kurulacak ordunun esasını vücuda getirmek, Kafkasyalı askerlere talim vermek ve Kafkasya'da yüksek İslam menfaatlerini ve hukuku mukaddesi Hilafet ve Türkiye ile siyasî rabıtayı ve askeriyeyi tesis etmektir. Bu teşkilat, tedrican büyük Rusya dahilindeki İslamlarla imkanı dairesinde teşkil edilecektir.

2 . Ordu kumandanı, Osmanlı hükümetinin ve İslam halifesinin Kafkasya'da en büyük mümessilidir.

3. Ordu kurmay başkanı yalnız askerî meselelerle meşgul olacak ve hiçbir suretle bunun haricindeki işlere müdahale etmeyecektir ${ }^{34}$.

On iki maddeden ibaret olan yetki belgesinin hiçbir maddesinde, Azerbaycan'ın ilhakının amaçlandığını gösterir en küçük ima dahi yoktur. Aksine yetki alanı kesin sınırlarla belirlenmiştir. Nuri Paşanın Gence'de takip ettiği politika da aynı istikamettedir.

Nuri Paşa 25 Mayıs 1918'de Gence'ye ulaştığında, büyük bir karşılama merasimi tertip edilmiş ${ }^{35}$ olmasına rağmen, Türkiye'ye duyulan şüphelerin de devam ettiği görülmektedir. Kafkas İttihat ve Terakki Partisi'nin, Kuzey

${ }^{32}$ Swietochowski., Müslüman Cemaatten..., S.181, Yusuf Hikmet Bayur, Türk İnkılap Tarihi, C.III, K.4, ANK., 1967, S.227.

${ }^{33}$ Dr. Mehmet Kengerli, Birinci Dünya Savaşı'ndan sonra 1950 sonlarında TC vatandaşı olmuştur. 1946 yılında Türk - İslam Eserleri Muhafaza Cemiye adıyla kurulmuş olan derneğin 1955 yılından bu yana değişik kademelerinde çalışmış, 15 yıldan beri de başkanlığını sürdürmektedir. 1954'te derneğin ismi Türk Anıtlar Derneği olarak değişmiştir. 96. yaşını sürdürmekte olan Dr. Kengerli, Musavvat Partisi'nin bugün yaşayan en yaşlı üyesidir.

${ }^{34}$ Süleymanov., Qafgaz İslam Ordusu ..., s.104. 105.

${ }^{35}$ Süleymanov., a.g.e., s.107, vd; İsmail Musayev, Azerbaycan Türkiye ilişkileri (19171922 yılları) Bakü, 1998, s.2, vd; Hasanlı., Azerbaycan Tarihi..., s.111, İslam Ordusu beş piyade tümeninden ibaretti. Gnr. Aliağa Şıhlinki'nin emrindeki Azerbaycan birlikleri de buna dahildi. Nuri Paşanın toplam askeri kuvveti 18 bin kişi idi. Türkiye'den 6000 erat gönderilmişti. Geriye kalan 12 bin kişi, yeterli askeri bilgiye sahip olmayan gönüllü Azerbaycan milisleriydi. 
ve Güney Kafkasya'nın Türkiye'ye ilhak olunmasını destekler mahiyetteki politikas $^{36}$, şüphelerin artmasındaki başlıca amildi.

Ahmet Refik Altınay da hatıralarında, Batum'un Kafkas murahhaslarıyla dolu olduğunu ve bunların çoğunun Türkiye ile birleşmeyi arzu ettiklerini belirtmektedir ${ }^{37}$. Tuğaç da, benzer şekilde Gence'de İttihad-1 İslam Partisi namına doktor Hüdadat Bey ile yaptığ $\breve{g}_{1}$ görüşmede, “... Türk ordusu gelsin, padişah isterse Azerbaycan'a muhtariyet verir. Dilerse Azerbaycan'1 ilhak eder. Kendi bilir." şeklinde düşündüğünü belirtmektedir ${ }^{38}$. Fakat, Kafkasya'da böyle düşünmeyenler de vardır.

Azerbaycan'ın bağımsızlığını kazanması için yapılan çalışmalar savaşın çok öncesinden başlamış olmakla birlikte, 1915 'den itibaren daha plânlı bir şekilde çalışıldı̆̆ı görünmektedir. 1915 senesi mayıs ayında Azerbaycan Cumhuriyeti kurma düşüncesinde olan "Difai" teşkilatının eski üyelerinden olan Aslan Hoyski cephe hattını geçerek Erzurum'da ordu karargahında Enver Paşa ile görüşmüştür. Türkiye'den yardım alarak bağımsız Azerbaycan Cumhuriyeti'ni kurmayı tasarlamaktadırlar ${ }^{39}$. Enver Paşanın da savaşın başından itibaren plânlarının Kafkasya'yı kapsadığı bilindiği için yardım isteklerini cevapsız bırakmasını düşünmek mümkün değildir. Yardım isteğinin sınırları ise açık ve nettir. Bu, bağımsız Azerbaycan Cumhuriyeti'nin kurulması olup, ilhakı amaçlamamaktadır. Millî Şûra'da Nasib Yusufbeyli de bu görüşü en güçlü müdafaa edenlerdendir. Hüsamettin Tugaç ile yaptığı görüşmede bu hususa şöyle açıklık getirmektedir. “Azerbaycan'a Türk ordusunun gelmesi... lazımdır, Ancak gördüğümüz bir nokta var, Türkler bizi İstanbul'dan idare etmeye kalkışmasınlar. Bizim adem-i merkeziyet üzerine kurulmuş programımız vardır, ona uymak gerekir." ${ }^{20}$. Tugaç, bu açıklamayı yeterli görmeyerek, Türkiye'nin Rusya'dan ayrı özellikleri olduğunu söyleyince, Nasib Bey, Azerbaycan'ın sosyal yapısının farklı olduğunu belirterek Bakü'nün bir endüstri ve işçi merkezi

${ }^{36}$ Süleymanov .,Qafgaz İslam Ordusu ..., 72,73, parti tarafından Mart 1918'de verilen beyanatta , Lenin'in, “... her millet kendi mukadderatına hakim olmalıdır.” Prensibine dayanılarak , Kafkasya'nın 6 milyonluk Müslüman ahalisinin anavatan Türkiye ile birleşmeyi talep ettiği ifade edilmekteydi."Ey Türk Ordusu, gel ! Gel , Cengiz ve Timurlenk'in izleri buradadır . biz büyüklerle gençler, sana iltihak etmek ve seninle beraber ecdat yurduna doğru yürümek için sana muntazırız...Yürü şarka yürü. Bil ki , sen yürüdükçe kızlarımız Kafkas defnelerinden başlarına çelenkler takacak ve milletimiz Kafkas dağlarından ayağına güller serecektir”, şeklindeki şiirlerle de Türk askerinin avdeti istenmekteydi.

${ }^{37}$ Altınay., Kafkas Yollarında..., s. 86

${ }^{38}$ Tugaç., Bir Neslin Dramı..., s.195-196

${ }^{39}$ Hasanlı., Azerbaycan Tarihi..., s. 30

${ }^{40}$ Nasib Nasibzade. Bölünmüş Azerbaycan Bütöv Azerbaycan. Bakı, 1997, s.101, vd; Süleymanov., Qafgaz İslam Ordusu..., s. 75, vd; Tugaç., Bir Neslin Dramı..., s. 194, Nasib Yusufbeyli, Adem-î Merkeziyet Partisi kurucularından olup, Bakü Kongresi sonucunda, Mehmet Emin Resulzade ile iş birliği yaparak, "Müsavat" Partisi ile birleştirmişti. Daha sonra millî komite başkanı olacaktı. 
olduğunu söylemişti. Bu sebeple sultan rejiminin Azerbaycan'a uymayacağını, Müsavat Partisi olarak halkın her sınıf ve tabakasının eşitliği üzerine kurulu bir idare tarzı düşündüklerini belirtmiş̧it ${ }^{41}$.

Naki Şeyhzamanlı da aynı görüşte olup, ilhak düşüncesine karşı çıkmaktaydı. Türkiye, Azerbaycan'ı ilhak etmek yerine, bağımsızlığının kazanılmasına yardım etmeliydi. Bu düşüncelerini Batum Konferansı görüşmeleri esnasında, Halil Bey'e de iletmiști. Halil Bey de benzer şekilde düşünmekte olup, ilhak edilmek isteği ile gelen bir grubu kabulünde, “... biz süngümüz ile Kafkasya'ya dahil olduk. Siz bize ilhak olmak istemeseydiniz de, biz süngü ile ilhak ederdik. Ancak buna imkan yoktur. Bizim birleşmemizi ne düşman ne de dost devletler kabul eder. Biz size yardım ediyoruz ve edeceğiz. İstiklâlinizi elde edip, müstakil yaşamanız için ne kadar lazım olsa asker göndereceğiz. Her taraflı kömek edeceğiz. Öz vatanımız gibi sizin vatanınızı da koruyacağız. Evlerinize gidin ve kurulacak istiklâli müdafaa edin., ${ }^{\prime 2}$ demişti.

Halil Bey'in düşüncelerinin, Enver Paşadan farklı olmadığı belli olmasına rağmen, Azerbaycan aydınları arasındaki şüphelerin devam ettiği görülmektedir. Nuri Paşanın Gence'ye gelişini müteakip, İslamî program takip eden ve ilhak düşüncesini müdafaa eden bazı gruplarla yakınlaşması bu tedirginliği arttıran sebeplerden bir diğeridir. 1918 Haziran ortalarında Nuri Paşanın Fetali Han Hoyski başkanlığındaki Azerbaycan Hükümeti'ne güvensizliğini ilan etmesi ile ülkede siyasî kriz çıkarken, bir taraftan da Nuri Paşaya duyulan güven kaybolmaya başlamıştır. Nuri Paşa bazı bakanların değiştirilmesini istemektedir. Millî Şûra temsilcileri Nuri Paşa ile görüşmek istediklerinde kabul edilmemişler ve Paşanın danışmanı Ahmet Ağaoğlu'na gönderilmişlerdir. $\mathrm{O}$ da, hükümet mensuplarını uyararak, halkın desteğini çektiğini, iç isyan çıkabileceği için istifa etmeleri gerektiğini söylemiştir. Aksi takdirde, Nuri Paşa hükümeti müdafaa edemeyeceklerini belirtmiştir. Ayrıca, Nuri Paşa yeni hükümeti belirleyecek hakka sahip olması gerektiğini söylemektedir ${ }^{43}$.

Nuri Paşanın danışmanı olan Ahmet Ağaoğlu'nun ilhakçı görüşteki Azerbaycan İttihat Partisi mensubu olması, hadiselerin büyümesine sebep olduğu kadar, Türkiye'ye duyulan güvenin azalmasına da sebep olmaktadır. Aslında Nuri Paşa, Azerbaycan Devlet idaresinde solcu görüşteki Himmet Partisi ve Müslüman Sosyalist Bloku'na dahil kişileri görmek

\footnotetext{
${ }^{41}$ Tugaç., Bir Neslin Dramı..., s. 194.

${ }^{42}$ Süleymanov .,Qafgaz İslam Ordusu ..., s. 82, vd; Naki Şeyhzamanlı hatıralarında, ilhakçılar ile mücadelenin çok daha çetin olduğunu, Ruslarla mücadelelerinde bu kadar sıkıntı çekmediklerini ifade etmektedir. İlhakçıların arasında vekil, hakim, şeyhülislam, tüccar, esnaf, mülk sahipleri, muallimler vardır. Yani güçlü ve eğitimli kesimden gelmektedirler. Bu güçlü grubun, Türkiye üzerinde tesirli olacağı korkusu hakimdir.

${ }^{43}$ ÍLM (İLiM) Gazetesi, 23 Eylül1989, Swietochowski., Müslüman Cemaatten..., S.180, Bayur., Türk Inkılâp Tarihi..., C.III. S.239-240.
} 
istememektedir. Bunun sonucu olarak da Fettali Han Hoyski kabinesini tasvip etmesi mümkün değildir. Çünkü mevcut hükümet bu yapısıyla daha çok Bolşevik Devrimi'nin tesirlerini taşımaktadır. ${ }^{44}$

Nuri Paşanın alenî bir şekilde Azerbaycan Hükümeti'nin iç işlerine karışması, Müsavatçılar arasında da hoş karşılanmamıştı. Durumu, “... aramıza nifak sokmaya gelmiş Osmanlı kardeşler” şeklinde ifade ediyorlardı. Karşılıklı güven kaybının arttığı görülüyordu. Millî Şûra'nın 17 Haziran 1918 tarihli toplantısında söz alan Nasib Yusufbeyli, Türkiye'nin ve Nuri Paşanın, Azerbaycan'ın bağımsızlığının korunması taraftarı olduğunu, dolaysıyla iç işlerine karıșmak niyetinde olmadı̆̆ını belirterek, Paşanın etrafının şüpheli şahıslarca sarıldığını ve onlara karşı ellerinden geleni yapmaları gerektiğini ifade etmişti ${ }^{45}$. Mehmet Emin Resulzade de aynı düşüncede olup, Nuri Paşa ile anlaşma yapılmasından yanaydı. Aksi takdirde, irticacı diye nitelendirilmekte olan islamcı ve ilhakçı görüşte olan grupların, Nuri Paşa üzerinde tesirli olmalarından korkuyordu.

Mehmet Emin Resulzade'nin devreye girmesi ile problem çözülmüş ve Fettali Han Hoyski kabineyi yeniden teşkil etmişti. Bu defa Nuri Paşanın istediği değişiklikler yapılmış ve önceki hükümetten sadece altı bakan yeni kabineye girebilmişti. Türkiye ile ilişkilerin geliştirilmesini istemeyen Moskova yanlısı olan temsilciler, hükümetten uzaklaştırılmıştı ${ }^{46}$.

Nuri Paşanın kabine değişikliğindeki ısrarlı tutumu, Türkiye aleyhindeki grupları haklı çıkarır nitelikte olmasına rağmen, o günün şartları çerçevesinde değerlendirildiğinde haklı olduğu görülecektir. 28 Mayıs 1918 'de istiklâl beyannamesini ilan etmiş olan Azerbaycan Millî Şûrası'nda başta "Müsavat Partisi mensupları olmak üzere Tarafsız Demokratlar Bloğu, Müslüman Sosyalistler Bloğu, Sosyalist Demokratik (Menşevik) ve Himmet Partisi grubu ile İslamî İttihat Partisi mensupları bulunmaktayd ${ }^{47}$. Bu durum hükümet içinde sürekli fikir ayrılıklarına sebep oluyordu. Nuri Paşa, ülkenin içinde bulunduğu olağanüstü şartlar sebebiyle de zaman zaman hükümet işlerine ve alınan kararlara müdahale mecburiyetinde kalıyordu. İslamî grupların, Türkiye ile yakınlaşma ve hatta Azerbaycan'ın ilhakını müdafaa eder tarzda politika ${ }^{48}$ takip etmeleri, Nuri Paşa bu düşünceye karşı olsa da, onlara karşı daha fazla teveccüh göstermesine sebep olmuş olmalıydı. Laiklik taraftarlarının, Türkiye aleyhindeki tutum ve davranışları da aynı şekilde bu hadisenin gelişiminde tesirli olan diğer bir faktördü. Fakat, bu hadiseler yine de, Azerbaycan tarihine "Haziran İrticası" olarak girecek ve Nuri Paşanın kabine değişikliğindeki ısrarının sebepleri ve günün şartları üzerinde hiç durulmayacaktı.

\footnotetext{
${ }^{44}$ Swietochowski., Müslüman Cemaatten..., S.180, Bayur., Türk Inkılâp Tarihi... S.240.

${ }^{45}$ Hasanl1., Azerbaycan Tarihi..., s. 109-110

${ }^{46}$ ILLM (ILIM) Gazetesi, 23 Eylül1989

${ }^{47}$ Nasibzade., Bölünmüş Azerbaycan..., s. 105

${ }^{48}$ Hasanlı., Azerbaycan Tarihi..., s. 107, vd; Guluyev., "Osmanlı Vesayeti" a.g.m.
} 
Hükümetin yeniden teşkilini müteakip, toprak reformu ile ilgili konunun uygulanması, Azerbaycan temsilciler meclisince onaylanıncaya kadar ertelenmiş, işçi sendikaları baskı altına alınarak sosyalist faaliyetler yasaklanmıştı. Halk arasında bu uygulamalar, Türk askeri, Rus devriminin getirdiği demokratik hakları kaldırıyor şeklinde yorumlanmaktaydı ${ }^{49}$. Halk, Lenin'in Azerbaycan'a, bilhassa da Bakü'ye yönelik niyetlerinden habersiz olduğu için rahatlıkla Türkiye'yi suçlayabilmekteydi. Türkiye'nin, Gürcistan'a ve Ermenistan'a resmî statüde büyük elçi tayin etmiş olmasına rağmen, henüz Azerbaycan'a elçi tayin edilmemiş olması da diğer bir eleştiri konusu idi ${ }^{50}$. Bütün bunlar Türkiye, Azerbaycan'1 ilhak edecek iddiasını müdafaa edenleri güçlendirmekteydi.

Türkiye aleyhine çalışan grupların bu husustaki şüpheleri bazen normal sinırları da zorlamaktaydı. Mehmet Emin Resulzade'nin, İstanbul konferansına gitmesi dahi, Nuri Paşanın kasti bir tavrı ve Azerbaycan'dan uzaklaştırma amacına yönelik bir uygulama olarak değerlendirilmişti ${ }^{51}$. Halbuki İstanbul Konferansı, Azerbaycan'ın bağımsızlığının uluslar arası boyutta kabul edilebilmesi için uygun bir zemin teşkil edecekti. Türkiye konferansta Almanya, Avusturya Macaristan ve Bulgaristan temsilcileri nezdinde, Azerbaycan'ın bağımsızlığının tanınması ve Bakü'nün resmî başkent olarak kabulü için yoğun çaba sarf etmek niyetindeydi. İlgili ülkelerde, Azerbaycan büyükelçiliklerinin açılabilmesi için de teşebbüste bulunulmaya başlanılmıştı ${ }^{52}$. İlhak amacında olduğu iddia edilen bir devletin, bu tarz bir politika takip etmesini izah etmek mümkün değildi. Fakat, Azerbaycan tarihçilerinin bir bölümünün Sovyet Rusya'nın tesiri ile bu görüşteki ısrarlarına devam ettikleri gibi, Mehmet Emin Resulzade'yi ve Müsavat Partisi'ni dahi zan altında bıraktıkları görülmektedir. Onlara göre, Resulzade'nin İstanbul'a gitmesinin sebebi, Azerbaycan'ın, Türkiye tarafından ilhakını temin etmekti. Gerçekte ise Resulzade, İstanbul'a gelmesini müteakip, Enver Paşaya bir mektup takdim ederek, "... Azerbaycan'ın bağımsızlığının korunmasının zaruriliğini göstermişti." Mektupta özetle, Türkiye'nin gücünün, Azerbaycan'ın bağımsız ve güçlü olması ile artacağı ifade edilmekteydi ${ }^{53}$. Bütün hayat1, Azerbaycan'ın bağımsızlığını temin etmek mücadelesi ile geçmiş ve öz yurdundan uzakta ömrünü tamamlamış bir vatansever için bu ithamlar fazlasıyla haksızdı. Cemil Hasanlı'ya göre; bu ithamı destekleyenler daha çok Sovyet ideolojisi tesirinde kalan tarih araştırmacılarıyd.$^{54}$

\footnotetext{
${ }^{49}$ ILLM (İLİM) Gazetesi, 23 Eylül1989, vd; Hasanlı., Azerbaycan Tarihi..., s. 108

${ }^{50}$ Nasibzade., Bölünmüş Azerbaycan..., s. 100

${ }^{51}$ Guluyev., "Osmanlı Vesayeti" a.g.m.

${ }^{52}$ Hasanlı., Azerbaycan Tarihi..., s. 141, vd; Firdovsiyye Ahmedova "Cumhuriyetin Dış Politikası" ILM (ILIM) Gazetesi, 28 Mayıs 1989

${ }^{53}$ Hasanlı., Azerbaycan Tarihi..., s. 112

${ }^{54}$ Hasanlı., Azerbaycan Tarihi..., S.5-22
} 
Nuri Paşa ve İslam Ordusu mensupları bu tartışma, suçlama ve hatta zaman zaman ortaya çıkan muhalefete rağmen Kafkasya'da bulunma amaçlarını asla unutmayarak 18 Eylül 1918'de Bakü'yü Bolşevik, Ermeni ve İngilizler'den müteşekkil işgalci güçlerden kurtarmışlardır ${ }^{55}$. Bu zaferin bedeli, 1200 Türk askerinin şehadetidir. Nuri Paşa ve silah arkadaşlarının Bakü'nün kurtarıcısı oldukları açıktı1 ${ }^{56}$. Tarih boyunca defalarca karşılıklı olarak gerçekleşmiş olan "Kardaş Kömeği" bu defa Türkiye'den Azerbaycan'a uzanarak gerçekleşmiştir.

Bakü'nün kurtarılmasından sonra korkulan olmamış ve Nuri Paşa devlet işlerine hiç karışmadığı gibi, ilhak amacına yönelik en küçük bir davranış içine girmediği görülmüştü. T. Svyatoçovski dahi bu görüşe katılarak, Nuri Paşanın artık Azerbaycan'ın iç işlerine karışma konusunda ihtiyatlı davrandığını, askeri meseleler hariç hiçbir işe müdahale etmediğini kabul etmektedir ${ }^{57}$.

Yapılan bütün fedakarlıklar nihaî olarak bağımsız Azerbaycan Cumhuriyeti'nin yaşaması ve devamını temin amacı ile olmasına rağmen, Mondros Müterakesi'ni müteakip, başta Nuri Paşa olmak üzere Türk askerî erkânı Azerbaycan'1 tahliye mecburiyetinde kalmış Türkiye'yi ve Nuri Paşayı zaman zaman haksız yere suçlamış olan Azerbaycan halkı kendi kaderi ile baş başa kalmıştı. Fakat Azerbaycan bağımsızlığını müdafaa edememiş ve Kasım 1918'de Gnr. V.M. Thomson'un kumandanlığındaki İngiliz, Fransız ve Amerikan birliklerinden oluşan müttefik askeri güçler, Bakü'yü işgal etmiştir. 27 Nisan 1920 gecesi de Rus ordusunun ani saldırısı ile Azerbaycan Demokratik Cumhuriyeti sona ermiştir. Azerbaycan Cumhuriyeti bağımsızlığını ancak 23 ay sürdürebilmiştir ${ }^{58}$.

Bugün Azerbaycan halkının büyük bölümü Nuri Paşayı ve Türkiye'nin 1918'deki yardımını daha farklı boyutta değerlendirmektedir. 15 Eylül 2000 tarihli "Azerbaycan gazetesi”ne göre; "20.yy.'ın başlangıcında BolşevikTaşnak zulmüne karşı, kardeş Türkiye'nin Azerbaycan'a yapmış olduğu yardımlardan bahsederken ilk akla gelen kuşkusuz ki Nuri Paşadır. Bu da tesadüf değildir. Çünkü Nuri Paşanın kumandanlığı ile Kafkas İslam Ordusu'nun Azerbaycan'da 1918 yılının haziran-ekim aylarındaki birkaç aylık faaliyeti binlerce insanı, hızla yayılmakta olan Bolşevik-Taşnak zulmünden kurtarmakla beraber, Azerbaycan'ın bağımsız devletçiliği üzerinde mevcut olan yakın tehlikeleri ortadan kaldırmıştır. Azerbaycan tarihinin en değerli sayfalarından biri olan ve doğu ülkelerinde demokratik devlet kuruculuğunun temelini koyan Azerbaycan Halk Cumhuriyeti şahsında Azerbaycan ve Türkiye askeri işbirliğinin kendine özgü yeri vardur".

${ }^{55}$ Mehmet Süleymanov "Nuri Paşa ve Onun Silah Arkadaşları" Azerbaycan Gazetesi, 15 Eylül 2000.

${ }^{56}$ a.g.m.

${ }^{57}$ Hasanl1., Azerbaycan Tarihi..., s. 141.

${ }^{58}$ Firdovsiyye Ahmedova "Cumhuriyetin Dış Politikası" ÍLM (İLIM) Gazetesi, 28 Mayıs 1989. 


\section{KAYNAKÇA}

Ahmedova, Firdovsiyye. "Cumhuriyetin Dış Politikası" ILM (ILIM) Gazetesi, 28 Mayis 1989.

Altınay, Ahmet Refik. Kafkas Yollarında, Ankara , 1986

Andican, Ahat. Azerbaycan Kültür Dergisi, Sayı: 315, Y11.47, 1997

ATESE ARŞ., Klas., 137, Doo., 632, Fih., 3, 3-1

ATESE ARŞ., Klas., 6863, Dos.34, F.1-5, 1-7,

Aydemir, Şevket Süreyya. Makedonya'dan Ortaasya'ya Enver Paşa 1914-1922, CIII, İstanbul, 1978

Aydemir, Şevket Süreyya. "Son Osmanlı Paşası Halil Kut'un Hatırası” Akşam Gazetesi (10 Aralık 1967).

Bayur, Yusuf Hikmet. Türk İnkılâp Tarihi, C.III, K.4, Ankara, 1967.

Berkok, İsmail. "Büyük Harpte Şimalî Kafkasya'daki Faaliyetlerimiz ve 15. Fırka'nın Harekâtı ve Muharebeleri" 94. Sayı, Askerî Mecmuanın 44 Sayılı Tarih Kısmı, İstanbul, 1934.

Cebesoy, Ali Fuat. Milli Mücadele Hatıralarım, İstanbul, 1953

Çelik, Dursun. "XIX ve XX. Yüzyıllarda Azerbaycan” Bilgi ve Kültür Dergisi, Sayı:3, 1996

Guluyev, Vilayet. “Osmanlı Vesayeti”, ILM (ILIM) Gazetesi, 23 Eylül 1989.

Hasanl, Cemil. Azerbaycan Tarihi, Ankara. 1998.

İLM (ILIM) Gazetesi, 23 Eylül 1989.

Kasımov, Musa. "20. Asır Azerbaycan Tarihinde; 1920-1922 Yıllarındaki Azerbaycan -Türkiye Diplomatik - Siyâsî Alâkalar" Aktaran: Hüseyin Adıgüzel, Türk Dünyası Araştırmaları, S:124, Şubat 2000/01

Keykuron, Naki. Azerbaycan İstiklâl Mücadelesinden Hatıralar (1905 - 1920), Ankara, 1998

Kurat, Akdes N. Türkiye ve Rusya, XVIII. Yüzyıl Sonundan Kurtuluş Savaşı'na Kadar Türk - Rus İlişkileri (1889-1919), Ankara, 1970

Mehmetzade, Mirza Bala. Milli Azerbaycan Hareketi, Ankara, 1991

Musayev, İsmail. Azerbaycan Türkiye ilişkileri (1917-1922 yılları) Bakü, 1998

Nasibzade, Nasib. Bölünmüş Azerbaycan Bütöv Azerbaycan. Bakı, 1997

Süleymanov, Mehman. Qafgaz İslam Ordusu ve Azerbaycan, Bakı, 1999

Süleymanov, Mehman. "Nuri Paşa ve Onun Silah Arkadaşları" Azerbaycan Gazetesi, 15 Eylül 2000.

Swietochowski, Tadeusz. Müslüman Cemaatten Ulusal Kimliğe Rus Azerbaycanı 1905-1920, Çev: Nuray Mert, İstanbul., 1988.

Tugaç, Hüsamettin. Bir Neslin Dramı, İstanbul, 1975

Yel, Selma. Yakup Șevki Pașa ve Askerî Faaliyetleri, Ankara, 2002

Yüceer, Nâsır. Birinci Dünya Savaşı'nda Osmanlı Ordusu'nun Azerbaycan ve Dağıstan Harekâtı Azerbaycan ve Dağıstan'ın Bağımsızlığını Kazanması 1918, Ankara., 1996. 


\title{
TÜRK İNKILÂP TARİHİ ENSTITTÜSÜ BELGE BAKIM ONARIM PROJESI
}

\author{
Arş. Gör. Alper BAKACAK
}

Üniversitemizin en eski birimlerinden biri olan Türk İnkılâp Tarihi Enstitüsü, Arşiv ve Kütüphanesi'ndeki belge ve kitapların kullanım, 1sı, ışık, nem, toz, bakteri, mantar ve benzeri çeşitli etkenlerden kaynaklanan yıpranma ve bozulma nedenlerinden dolayı belge bakım ve onarım projesi başlatmıştır. Bu proje çerçevesinde ilk aşamada arşiv belgelerin içinde yıpranmış olanların bakım ve onarımı yapılacaktır. İkinci aşamada eski gazetelerin ve üçüncü aşamada ise eski kitapların bakım ve onarımına geçilecektir.

Konu ile ilgili olarak Enstitümüz iki elemanına Genelkurmay ATASE Başkanlığı Arşivi'nde eğitim verilmiş ve bu projenin gerçekleştirilmesi için gerekli özel malzemeler sağlanmıştır.

Sözü edilen özel malzemelerin başında belge onarımı için kullanılan kağıt gelmektedir. Japonya'da üretilen ve Almanya'dan ithal edilen bu kağıt, yapıştırılan belgeye herhangi bir zarar vermediği gibi bir süre sonra asıl kağıda nüfuz ederek kaybolmaktadır. Bu sayede yıpranmış kağıt üzerindeki yazılar özel kağıda aktarılmaktadır. Bu işlem için kullanılan yapıştırıcı da Amerika Birleşik Devletleri'nden ithal edilmektedir. Kullanılan yapıștırıcı, şeker ve kağıda zarar verebilecek bir başka kimyasal birleşen içermemektedir.

Yaşama geçirilen projenin dışında, belge, kitap ve gazete koleksiyonlarının, özellikle 1sı, 1şık, toz ve nemden korunması için Arşiv, Kütüphane ve Müze bölümlerimizde tadilat projesi hazırlanmış olup yakın bir zaman içinde uygulamaya konulacaktır.

Not: Dergimizin bundan sonraki sayılarında Enstitümüzdeki çalışmalarla ilgili bilgiler ve Türkiye'de ve Türkiye dıșında Cumhuriyet Tarihi ile ilgili haberler de kısaca yer alacaktır. Ayrıca Enstitümüze iletilmesi durumunda, konuyla ilgili olan herkesin haber niteliği taşıyan yazılarına dergimizde yer verilecektir. Haber nitelikli yazılarını yayınlamak isteyen okuyucularımız aşağıdaki adresler ile bize ulaşabilirler. 
İrtibat Adresi: Ankara Üniversitesi Türk İnkılâp Tarihi Enstitüsü 06280 Keçiören Yolu/ANKARA

Gıda Mühendisliği 4 No'lu Bina Zemin Kat

E. Mail Adresi: tite@humanity.ankara.edu.tr 


\section{“ATATÜRK YOLU” DERGISIINDE YAYINLANACAK MAKALELER İÇİN BİLGİ NOTU}

\section{Genel Kurallar}

1. Atatürk Yolu dergisi Mayıs 2002 tarihinden itibaren "Hakemli Dergi" statüsünde ve yılda iki kez (Mayıs-Kasım aylarında) yayımlanacaktır.

2. Dergiye gönderilen yazılar daha önce başka yerde yayımlanmamış veya yayımlanmak üzere aynı anda başka bir yere gönderilmemiş olmalıdır. Yazılar kabul edildiği andan itibaren "Atatürk Yolu" dergisi tüm yayın haklarına sahiptir.

3. Dergiye gönderilen yazılar, Danışma Kurulu tarafından ilk değerlendirilmesi yapıldıktan sonra hakemlere gönderilecek ve hakemden gelecek rapor doğrultusunda yazının basılmasına, hakem raporu doğrultusunda düzeltme istenmesine veya geri çevrilmesine karar verilecektir. Durum en kısa sürede yazarına bildirilecektir.

4. Derginin bir sayısına fazla yazı gelmesi durumunda yazarın da onayı alınarak yazı bir sonraki sayıda yayımlanabilecektir.

5. Yazarlar, unvanlarını, görev yaptıkları kurumları, haberleşme adresleri, telefon belgegeçer numaralarını bildireceklerdir.

6. Dergiye gönderilen yazılar (disketi ile birlikte) teslim alındıkdan sonra düzeltme için yazara geri gönderilmeyecektir. Çok fazla yazım yanlışı bulunan yazılar geri çevrilecektir.

7. Yazısı kabul edilen yazara derginin yayımlanmasından sonra telif ücreti ödenecektir.

8. Dergide yayımlanan yazıdan 20 adet tıpkıbasım ve 5 adet dergi yazara ücretsiz olarak gönderilecektir.

\section{ATATÜRK YOLU” Dergisi Yazı Formatı}

1. Türkçe makale başlığının altına özetin yazıldığı yabancı dildeki karşılığı, makale yabancı dilde yazılmış ise Türkçe karşılı̆̆ı yazılacak,

2. Makale adı ve yazar adından sonra 200 'er kelimeyi geçmeyecek şekilde Türkçe özet “ÖZ” ve yabancı dilde özet “ABSTRACT” yazılacak,

3. Makale yazımında; (yazı tipi Times New Roman) 
a) Başlık 14 punto koyu, yabancı karşılığı 13 punto normal ve her iki dilde de kelimelerin ilk harfleri büyük; yazar adı 12 punto koyu; Öz ve Abstract 10 punto italik; metin 11 punto normal, dipnotlar 9 punto, kaynakca 10 punto yazılacak,

b) Metinde satır aralığı 1 (tek), paragraf başı boşlukları 0.5, dipnot başlangıçları 0.5 olacak,

c) Makale içindeki ana başlıklar metnin yazıldığı puntoda, boşluk bırakılmadan, koyu ve küçük harflerle yazılacak, alt başlıklar hiyerarşik bir yapı izlenerek oluşturulacak ve tek biçimlilik sağlanacak,

d) Dipnotlar aynı sayfa altında verilecek,

e) Dipnotlarda ve/veya kaynakçada yayın adları (kitaplarda kitap adı, makalelerde dergi adı) italik yazılacak, atıflarda alıntı yapılan sayfa numarası mutlaka belirtilecek,

f) Atıfta bulunulan kaynağın tam kimliği verilecek, atıfta bulunulmamış eserler verilerek kaynakca şişirilmeyecek,

g) Kaynakçada yazar adları küçük harflerle yazılacak,

h) Sayfa numarası altbilgi/üstbilgi kısmından verilecek,

i) Üstbilgi alanından çift numaralı sayfalara yazar adı, tek numaralı sayfalara makale adı 9 punto yazılacak

j) Her makalenin başlangıcında, makalenin kimlik bilgisi verilecek, (Örn. Ankara Üniversitesi Türk İnkılâp Tarihi Enstitüsü Atatürk Yolu Dergisi, S. 22, Kasım 1998, s. 1-10).

4. Ekler yazının sonunda verilecek ve altında belgenin içeriği hakkında kısa bir bilgi ile bilimsel kaynak gösterme ölçütlerine uygun bir şekilde kaynak yer alacaktır.

\section{Haberlesme Adresi: Ankara Üniversitesi Türk Inkılâp Tarihi Enstitüsü \\ Gıda Mühendisliği 4 nolu bina zemin kat No. 2/4 06280 Keçiören / ANKARA}

Tel: (0312) $3604013 \quad$ Belgegeçer: (0312) 3594308 